\title{
Predicting Consumer Behavior: An Extension of Technology Acceptance Model
}

\author{
Mohammad Hasan Galib ${ }^{1}$, Khalid Ait Hammou ${ }^{1} \&$ Jennifer Steiger ${ }^{1}$ \\ ${ }^{1}$ California School of Management and Leadership, Alliant International University, 10455 Pomerado Rd, San \\ Diego, CA 92131, USA \\ Correspondence: Mohammad Hasan Galib, California School of Management and Leadership, Alliant \\ International University, San Diego, California, USA.
}

Received: June 6, 2018 Accepted: July 2, 2018 Online Published: August 21, 2018

doi:10.5539/ijms.v10n3p73 URL: https://doi.org/10.5539/ijms.v10n3p73

\begin{abstract}
The purpose of this study is to examine the predictive power of the technology acceptance model (TAM) on customer's intention to participate in the social customer relationship management (sCRM) program. Three additional constructs, perceived risk, user satisfaction, and perceived enjoyment were added to the original TAM. The collected data $(n=264)$ were subject to statistical analysis of structural equation modeling, exploratory and confirmatory factor analysis. The study reveals that TAM by itself is not a robust model to predict customer's intention to participate in the sCRM program. Among the original constructs of TAM, attitude is the only determinant of intention. The impact of perceived usefulness and perceived ease of use was not significant on intention. Among the extended variables, perceived risk is the only variable that significantly influenced intention; perceived enjoyment and user satisfaction did not have any impact on intention. By applying the TAM to the sCRM, this study extends the overall body of the theoretical knowledge surrounding technology acceptance.
\end{abstract}

\section{Introduction}

The goal of every enterprise is to acquire, retain, and increase the number of customers. Until the 1980s, most enterprises focused their marketing strategies on acquiring and retaining customers by developing an efficient marketing mix of the four Ps (product, price, place, and promotion). Generalized marketing messages were sent to all potential customers through mass media. In the early 1990s, companies started to realize the need for customized messages and the importance of customer retention. Therefore, companies began shifting their focus from acquisition of new customers to maintenance, enhancement, and retention of existing customers through numerous strategies and tactics called Customer Relationship Management (CRM) (Baran et al., 2008). CRM is an emerging concept and it is a kind of e-business strategy that empowers the organization to better manage relationships with their customers using social technologies (Chen \& Vargo, 2014). The underlying premise of CRM is that firms create customer knowledge in order to (1) effectively segment customers, (2) develop and maintain long-term relationships with profitable customers, (3) determine how to handle unprofitable customers, and (4) customize market offerings and promotional efforts (Sirivastava, Shervani, \& Fahey, 1999). A CRM strategy aims to create a comprehensive customer-centric strategy that contributes to durable relationships with customers and makes a profit for owners (Soltani \& Navimipour, 2016).

The paradigm shift from focusing on attracting new customers to retaining current ones is at the backbone of CRM (Winer, 2001). Studies revealed that small increases in customer retention rates greatly increased profits, proving that long term customers can be more valuable and more revenue on average is generated from repeat-purchase customers when compared to one-time buyers (Reichheld, 1996). Company must focus on building unique, one to one relationships with customers based on individual needs and wants; thus, implementing customer relationship management is critical to the growth and future success of firms. The better relationships the company has with the customer, the more opportunities it will avail to learn about the customer's behavior.

The growth of social media technology has considerably changed relationships between companies and their customers (Harrigan, Soutar, Choudhury, \& Lowe, 2015). The mixing of social media technology inside a CRM strategy is a rising circumstance, leading to an innovative efficient model which can be explained as social CRM 
(Harrigan \& Miles, 2014). Social CRM is the process of converting content into conversations, extending those conversations into collaborative experiences, and then transforming those experiences into meaningful relationships (Walsh, 2010). Even though CRM stands for customer relationship management, in the social CRM environment, the company no longer controls the relationship; the control has shifted to the customer. Social CRM puts the customer at the core of the company's strategy. The basic premise of social CRM is that the firm is able to interact with its customers based on customers' needs, not the firm's predefined rules, thus opening the door to a permission-based dialogue between a firm and its current and potential customers. Therefore, social CRM is a dialogue-based marketing solution supported by information system tools that help firms not only to sell but also to know what happens in customers' minds, why customers are dissatisfied, why customers like a firm's products, what problems customers have, and how firms can make customers satisfied again (Bago, 2011). Social CRM creates a two-way interaction between parties and gives customers ownership over the conversation with the firm (Shimp, 2010; Greenberg, 2009).

\section{Gaps in Research}

The usage of CRM continues to grow in the industry at an astounding rate. Since 2011 each year around $70 \%$ of businesses have stated they plan to increase spending on CRM in a consistent basis (CosmosCRM, 2016). According to market research firm Gartner, worldwide CRM implementation totaled $\$ 23.2$ billion in 2014, up 13.3 percent from 20.4 billion in 2013; the CRM usage increased from $56 \%$ to $74 \%$ in 2015 (Gartner, 2015). Forecasts from Gartner anticipate that the CRM market will be worth $\$ 36.4$ billion worldwide by 2017 (CosmosCRM, 2016). Despite the consistent growth and continuous investment on CRM implementation at a staggering rate, little research has been undertaken to explore the behavioral aspect of consumers in the CRM domain.

The CRM implementation success rate is disappointing. CRM initiatives currently have a $63 \%$ fail rate and 53\% of this failure is primarily due to the lack of clear understanding of customer insight (Direct Marketing News, 2013). Between $25 \%$ and $60 \%$ of CRM projects fail to meet expectations in the last decade (CosmosCRM, 2016). One of the requirements of CRM success is to make the marketing strategy customer-centric. Most companies fail to achieve their desired benefits of CRM because of the failure to put the customers in the center of their marketing strategy. Companies are developing product-centric strategy without conducting adequate customer-centric research.

The technology acceptance model (TAM) has been applied in a variety of studies testing user acceptance of information technology that includes green IT (Yoon, 2018), mobile app (McLean, 2018), digital library (Xu \& Du, 2018), Social media usage (Hansen, Saridakis, \& Benson, 2018), Virtual learning (Belletier, Robert, Motak, \& Izaute, 2018), work processing (Davis et al., 1989), spreadsheet application (Mathieson, 1991), web browser (Dillon \& Morris, 1996), telemedicine (Hu et al., 1999), e-mail (Szajna, 1996), wallet phone (Swilley, 2010), blackboard (Landry, Griffeth, \& Harthman, 2006), m-commerce (Snowden et al., 2006), communication technologies (Zaremohzzabieth et al., 2015), online purchase (Chiu et al., 2005), e-collaboration (Dasgupta, Granger \& Mcgarry, 2002), and websites (Koufaris, 2002). Since social CRM is relatively a newer field of study, TAM has not been examined in this new domain of social CRM. Therefore, the predictive power of TAM is still unknown in social CRM. This study will fulfil this research gap.

Although numerous studies have been undertaken on CRM, little effort has been made to explore the customers' intention to participate in the social CRM program. The majority of CRM research studies focuses on the organizational and management-related factors to explore the causes of high failure in CRM implementation. Therefore, customer behavior remains an under-focused area for marketing researchers in the CRM world. As customer participation is one of the key factors for social CRM success, it is imperative for marketers to identify what factors influence customers' decision to participate in social CRM programs.

\section{Purpose of the Study}

Customer participation is a prerequisite for the success of any IT application and CRM is not an exception. Previous research studies found that user acceptance of CRM is an essential factor for its success (Corner \& Rogers, 2005; $\mathrm{Wu} \& \mathrm{Wu}, 2005)$. In a controlled environment, customer's intention is the immediate and direct antecedent of behavior. Although extant literature provides helpful insight into the company's point of view, researchers have shown little concern about the potential gap between CRM activities and customer's willingness to participate in the CRM program (Kim, Park, Dubinsky, \& Chaiy, 2012). The majority of the existing CRM research has focused only on the company side of CRM implementation (Jallat \& Ancarani, 2008). Therefore, marketing academicians have overlooked customer's perceptions towards participating the CRM program. To fill this gap, this study attempts to investigate the factors that influence customer's intention to 
participate in the social CRM program. One of the most widely used models to predict consumer technology acceptance is the TAM and it has been considered the most validated model for explaining the acceptance of IT and information systems in recent decades ( $\mathrm{Lu}, \mathrm{Yu}, \mathrm{Liu}, \& \mathrm{Yao}, 2003)$. The main reason for its popularity is its parsimony and the empirical support for it (Agarwal \& Prasad, 1997; Adams et al., 1992). Therefore, the objective of this study is to examine the predictive power of the TAM on customer's intention to participate in the social CRM program. In order to achieve this goal, this study will investigate the factors that influence the customer's intention to participate in the social CRM program by employing the TAM as the research framework. This will help increase the current understanding of customer's acceptance of social CRM.

\section{Research Model}

TAM is an intention-based model derived from the Theory of Reasoned Action (TRA) but tailored to meet the broad needs of information technology research (Davis et al., 1989). It was introduced by Davis (1989) to explain an end-user's computer acceptance using a parsimonious and theoretically justified model. TAM proposes that an attitude towards technology acceptance and subsequent use is comprised of the belief component (usefulness) and perception that the belief is attainable with the targeted behavior (ease of use) (Davis, Bagozzi, \& Warshaw, 1989). Previous research has continuously reported that the TAM was very useful in predicting and explaining technology use in various situations (Dillon \& Morris, 1996).

TAM has evolved in the last two decades, and many researchers have developed new models by adding variables to the TAM in order to increase its explanatory power. Davis (1989) also argued that research should explore other variables that could affect perceived usefulness, perceived ease of use, and actual usage. Dishaw and Strong (1999) noted that one of the weaknesses of the TAM is its lack of explicit inclusion of external variables. As an extension of the TAM, Dishaw and Strong (1999) added new variables that include the relation between task-technology fit to the existing TAM and their new extended TAM model explained the variance of the dependent variable better than the original TAM. In a study to explain the participants' usage behavior on the World Wide Web, Moon and Kim (2001) added a new variable "perceived playfulness" to the existing TAM. In another study of bulletin board systems, Mathieson and Chin (2001) developed a new model by adding the variable of "perceived user resources" to TAM. In testing consumers' intention to adopt e-commerce, Pavlou (2002) developed a new model by incorporating two additional factors: trust and perceived risk. Similarly, numerous extended variables with specific contexts have been added to TAM: Teo, Lim, and Lai (1999) introduced the variable "perceived enjoyment" in a study of Internet usage, and Luo and Strong (2000) proposed the variable "perceived critical mass" in their study of groupware usage. Recent important additions to the TAM include the constructs of "perceived risks," "perceived enjoyment," "internet usage," and "previous online shopping experience" (Jarvenpaa \& Todd, 1997; Bhatnagar, Misra, \& Rao, 2000; Childers et al., 2001; Park \& Jun, 2003).

In addition to TAM's original variables, attitude, perceived usefulness, perceived ease of use, and intention, current study added three new variables, perceived risk, perceived enjoyment, and user satisfaction in order to predict the participants' intention to participate in social CRM. The reasons that these constructs were picked will be explained in the next section.

\section{Hypothesis Development}

Based on the theoretical model of TAM with three additional variables, this study develops a research model (Figure 1) and proposes the following constructs and corresponding hypotheses with regard to intention to participate in the social CRM program.

\subsection{Attitude Towards Participating in Social CRM (ATCRM)}

Attitude has been one of the central concepts for research in psychology and behavioral science for many years. Fishbein and Ajzen (1975) defined attitude as "a person's favorable or unfavorable evaluation of an object." Attitude has long been identified as a cause of intention (June, Chun-Seng, Chang, \& James, 2003). A positive relationship between attitude and usage intention has been supported in a variety of research contexts (Sheppard et al., 1988; Yousafzai, Foxall, \& Pallister, 2007). Taylor and Todd (1995) found attitudes to be predictive of the intention to use IT. In a research study on e-commerce, Pavlou (2002) found that the consumer's attitude towards using online services is a predictor of the consumer's behavioral intention. The relationship between attitude and intention in a technology-based context has also been confirmed by Shin (2007). This current research study defines ATCRM as the degree of an individual's positive or negative feelings about participating in social CRM. Users who participate in social networking sites can develop effective ties with other participants (Gruen et al., 2006). These relationships may have a positive impact on participants' intention to engage in social CRM programs. Similarly, negative comments from other users in the social media may have negative influence on 
participants' intention to engage in social CRM programs. Since attitude has previously been identified as a cause of intention (June, Chun-Seng, Chang, \& James, 2003), this study constructed the following hypothesis.

H1: Attitude towards social CRM significantly affects the intention to engage in social CRM programs.

\subsection{Perceived Usefulness (PU)}

Davis (1989) defined PU as the "degree to which a person believes that using a particular system would enhance his or her job performance." The TAM's PU was based on previous motivation, expectancy theory, and information systems research performed by Askool and Nakata (2010); Choudhury and Harrigan (2014). Prior studies have documented the importance of PU in information system adoption (Chiu, Lin, \& Tang, 2005; Cheong \& Park, 2005; Pikkarainen, Pikkarainen, Karjaluoto, \& Pahnila, 2004). Chiu et al. (2005) found that PU positively influences online purchase intentions. The result of this study indicates that consumers are likely to consider the online purchase when they find online environment is useful for making purchases. Pikkarainen et al. (2004) found that PU was positively correlated with online banking use. The current research study defines $\mathrm{PU}$ as the degree to which a person believes that participating in the social CRM would increase his or her satisfaction as a customer.

There has been wide support for the hypothesis that PU positively relates to computer and technology adoption research. Thus, this study incorporated the following two hypotheses with regard to PU of social CRM programs.

H2a: Perceived usefulness positively affects intention to engage in social CRM programs.

$H 2 b$ : Perceived usefulness positively affects attitude towards social network.

\subsection{Perceived Ease of Use (PEU)}

PEU is defined as the degree to which an individual believes that using a particular system would be free of physical and mental effort (Davis, 1989). Adams, Nelson, and Todd (1992) found that system usage relied on both PU and PEU determinants. The easier a technology is to interact with, the greater should be the user's sense of efficacy; efficacy is thought to operate autonomously from instrumental determinants of behavior (Chung, 2005). The current research study defines PEU as the degree to which a person believes that participating the social CRM would be free of effort. Empirical studies in applying the TAM have verified that PEU has a strong effect on user acceptance of an application (Askool and Nakata, 2010; Harrigan and Choudhury, 2014; Ramayah, 2006). Therefore, this study incorporated the following hypothesis with regard to PEU of social CRM programs.

H3a: Perceived ease of use positively affects attitude towards social network.

$H 3 b$ : Perceived ease of use positively affects perceived usefulness.

\subsection{Perceived Enjoyment (PE)}

Enjoyment is a major factor that drives users to use a new technology (Bruner \& Kumar, 2005; Davis, Bagozzi, \& Warshaw, 1992). When someone enjoys spending time with any technology or software or application, it is obvious that the person's intention to participate in or use the technology will be high. Individuals engage in activities because these activities lead to enjoyment and pleasure (Teo \& Lim, 1997). PE is defined as the extent to which the activity of using a technology is perceived to be enjoyable in its own right, aside from any performance consequences resulting from technology use (Venkatesh, 2000). PE as an intrinsic motivation has been found to have a significant impact on a user's technology acceptance, especially for hedonic systems (Davis, Bagozzi, \& Warshaw, 1992); Teo et al., 1999; Igbaria, Iivari, \& Maragahh, 1995; Pikkarainen et al., 2004; Davis, Bagozzi, \& Warshaw, 1992; Nysveen, Pedersen, \& Thorbjornsen, 2005; Amin, Baba, \& Muhammad, 2007). Teo et al. (1999) found that PE has a positive effect on frequency of Internet usage because of the fun, excitement, flexibility, and pleasure associated with it. Nysveen et al. (2005) reported a strong correlation between PE and usage intention of mobile chatting. The current research study defines PE as the extent to which spending time in social media is perceived enjoyable. This study incorporated the following hypothesis about PE.

H4: Perceived enjoyment positively affects intention to engage in social CRM programs.

\subsection{User Satisfaction (US)}

US is a widely studied construct as a predictor for future system usage of similar products. Satisfaction can be defined as the degree to which the user of the system believes the system performs satisfactorily for its intended use (Seddon, 1997). Homberg et al. (2002) defined customer satisfaction as positive disconfirmation of expectations, which means that perceived performance is equal to or better than the expected outcome. According to the expectation-confirmation theory (Oliver, 1980), a customer has expectations of a good or service prior to its consumption. If any good or service meets the customer's expectation, it can be expected that 
previous usage experience and satisfaction will have a positive impact on the customer's intention for future purchases. In the current research study, US with social media was measured to examine the effect on the user's intention to participate in social CRM programs. Prior research has suggested that satisfaction plays an important role in affecting customers' decisions regarding the purchase of goods and services (Yi, 1989). Therefore, this study incorporated the following hypothesis with regard to US.

H5: User satisfaction positively affects intention to engage in social CRM programs.

\subsection{Perceived Risk (PR)}

PR has been studied in the field of marketing for almost half a century, and researchers have found this construct as an essential element of consumer behavior. Perception of risk is a pivotal aspect of consumer behavior because it often produces anxiety that consumers must deal with (Taylor, 1974). PR refers to the degree to which psychological risks are attributed to a product (Gatignon \& Robertson, 1985; Herbig \& Day, 1992). PR is the expected negative utility associated with the purchase of a particular product or brand (Dunn, Murphy, \& Skelly, 1986). The current research study defines PR as the degree to which a person believes the potential threat of losing his or her personal and financial data associated with participating a social CRM program. Previous studies have suggested that PR is an important factor for consumer technology usage. For example, studies found a negative relationship between PR and intention to shop online (Bhatnagar et al., 2000; Park, Lennon, \& Stoel, 2005). A similar relationship was found in online auctions (Pavlou \& Gefen, 2004), Internet banking (Kim \& Prabhakar, 2000), and online shopping (Bhatnagar et al., 2000; Forsythe \& Shi, 2003). Therefore, this study incorporated the following hypothesis with regard to PR

H6: Perceived risk negatively affects intention to engage in social CRM programs.

\subsection{Intention to Participate in Social CRM (INT)}

Behavioral intentions can be defined as an individual's anticipated or planned future behavior (Swan, 1981). When the person has complete control over the behavior in question and when the behavior is completely voluntary, intentions alone should adequately predict behavior (Ajzen \& Fishbein, 1980). In other words, intention can be assumed to be the immediate antecedent of behavior. Results of numerous studies have supported the notion that behavioral intentions affect behavior positively (Hung et al., 2003; Tung, 2004; Nysveen et al., 2005). The current research study defines intention to engage in social CRM as the probability that an individual will participate in the social CRM program. In the current research model, intention to engage in social CRM was considered a dependent variable.

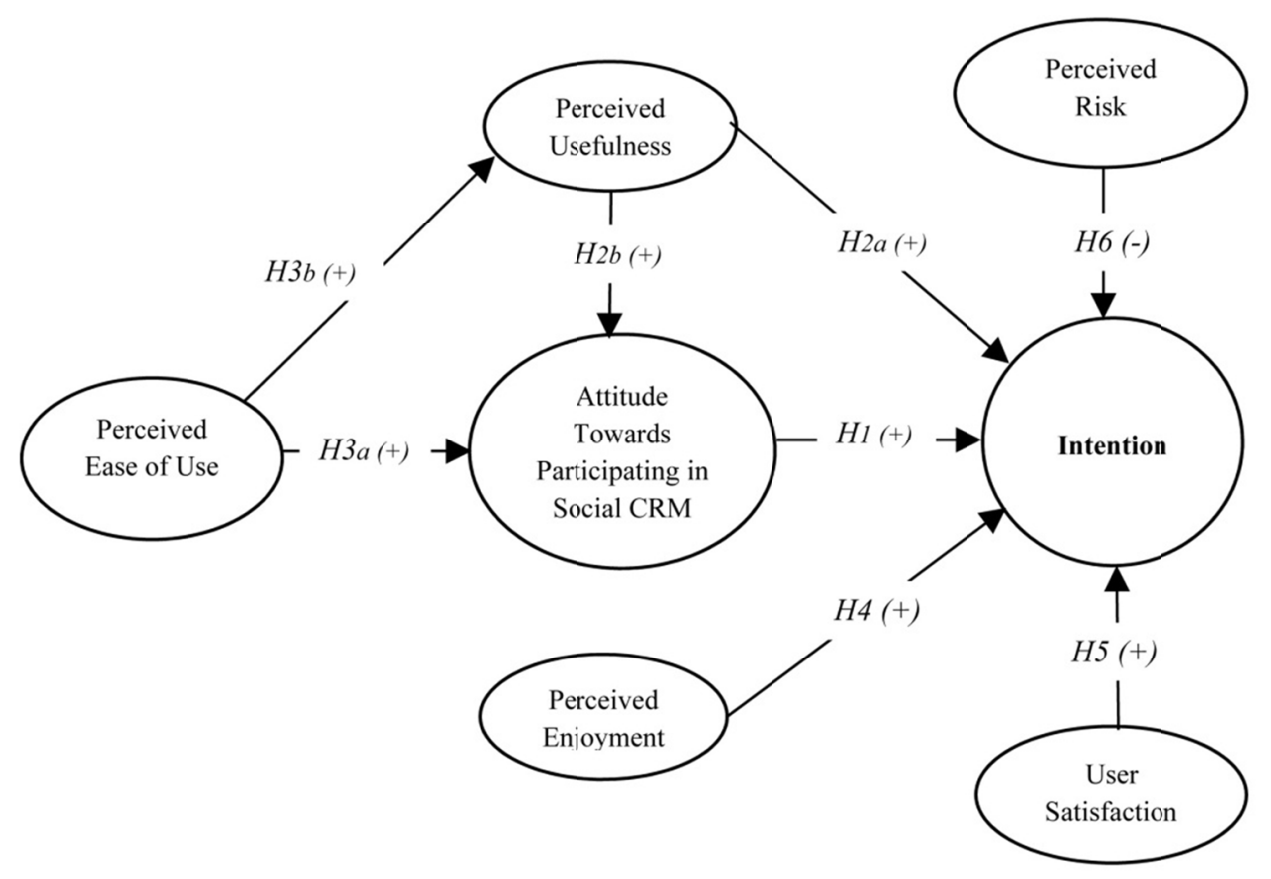

Figure 1. Research model 


\section{Research Methodology}

\subsection{Instrument Development}

This research study utilized a survey instrument that featured closed-ended questions. The scales adapted in this survey instrument have been used in previous TAM related researches (e.g., Pan, 2003; Siegel, 2008) and have been modified to fit in the current study in the social CRM context. The demographic questions included gender, age, income, ethnic background, educational background, preferred social networking site, and social media usage. All items were measured on a 7-point Likert-type scale.

\subsection{Data Collection}

The participants of this study were the adults living in USA who were active in social media. Data for this study were collected from January to March 2018 through a self-administered web-based survey instrument using Qualtics using multiple sources. The survey link was posted in numerous online forums for students, researchers, social community groups, professional forums, general discussion forums, question-and-answer forums, blogs, and social networking sites such as Facebook, Twitter, and Google+. Additionally, an e-mail message with a link to the web survey was distributed to potential participants.

\subsection{Pilot Study}

A pilot study that included 30 participants was conducted for two weeks. The feedback from the participants of the pilot study helped the researcher make changes to the questionnaire so that the final participants could understand and reply to all questions without difficulty.

\subsection{Demographic Profile}

There were 921 people participated in this study; only 305 of them successfully completed the survey. Out of 305 participants, $155(51 \%)$ were female and $150(49 \%)$ were male. The largest $(50.2 \%)$ age group was in 19-30 years old, followed by the group of 31-40 years old with $25.9 \%$. Thirty seven percent of the participants has master's degree, $25 \%$ has bachelor's degree, and $14 \%$ has doctoral degree. This distribution demonstrates that the majority of the participants (76\%) are educated, holding bachelor's degree or higher. Approximately, $22 \%$ of the participants has annual income less than $\$ 40,000,12.8 \%$ has income between $\$ 40,000$ and $\$ 60,000$, and $12 \%$ earns more than $\$ 80,000$. The largest segment (59\%) of the participants is Caucasian, followed by Asian (22\%). The most popular social media site is Facebook, followed by Linkedin, Twitter, and Google Plus. Majority of them use more than three sites, accounting for one-third of the total participants, $90 \%$ use Facebook, 57\% use Linkedin, $44 \%$ use Twitter, and $41 \%$ use Google Plus.

\subsection{Data Screening}

The assumptions for factor analysis are the existence of linear relationships, the absence of outliers, the lack of high multicollinearity, and the presence of multivariate normality. Before proceeding with the data analysis, all variables were screened for possible code and statistical assumption violations. Additionally, data were screened for finding missing values and outliers using SPSS frequencies, explore, plot, and regression procedures.

\subsubsection{Linearity}

The result of the linearity test through examining scatterplots and $R^{2}$ linear value shows that all $R^{2}$ linear values are between 0.022 and 0.418 . This result demonstrates the existence of linear relationships in the sample data.

\subsubsection{Outliers}

Univariate outliers were examined by computing the standardized scores $(z)$ of each variable. Hair et al. (1998, p. 99) recommended considering cases with $z$ scores exceeding \pm 2.5 to be outliers and thus deleting them. In this study, outliers exceeding this recommended value of \pm 2.5 were deleted. Multivariate outliers were examined by computing the Mahalanobis distance. Cases with a Mahalanobis distance of more than $22.46(p<.001)$ were considered multivariate outliers and deleted from the dataset. By following the guidelines of univariate and multivariate outliers, 41 cases were removed as outliers. After removing these data as outliers, the final count for data analysis was 264.

\subsubsection{Multicollinearity}

In order to examine the multicollinearity in the data, a series of multiple regressions were conducted. In this series of tests, each independent variable was treated as a dependent variable, and all other remaining independent variables were considered independent variables. A tolerance value less than .10 or a variance inflation factor (VIF) above 10 indicates high collinearity (Hair et al., 1998, p. 746). The result of the multicollinearity test shows that all the tolerance values are between .679 and .986 and the VIF values are 
between 1.014 and 1.444. Thus, the values of tolerance and the VIF values are within the acceptable limits. This result demonstrates that the sample data do not have the presence of high multicollinearity.

\subsubsection{Normality}

The distribution of the data was examined using skewness and kurtosis for confirming the normality. The skewness and kurtosis values of all variables used in this study were within \pm 2 . The results of all of these tests confirmed the normality distribution of the dataset.

Although the constructs of this study were adapted from previous studies with acceptable validity and reliability, the validity and reliability of those constructs were retested in this study. In order to verify how closely the survey measurements met the objectives of this study, a reliability test was performed to test the proposed model. Construct validity was established in this study by proving the measures provide reliability, content validity, convergent validity, unidimensionality, and discriminant validity.

\subsubsection{Reliability}

A measure to test how well a set of constructs measures an underlying construct, Cronbach's alpha is widely used to measure the reliability of the constructs. Therefore, Cronbach's alpha was employed for testing the consistency between multiple measurements of the research variables of the current study. A Cronbach's alpha value of 0.70 or more is generally considered to be acceptable reliability (Creswell \& Miller, 2000; Chau, 2001; $\mathrm{Wu}$, Chang, \& Guo, 2008). In this study, internal consistency of the construct ranged from .702 for US to .915 for ATCRM. These values for Cronbach's alpha are a significant indication of high reliability. Reliability coefficients are presented in Table 1.

Table 1 . Reliability coefficients

\begin{tabular}{ll}
\hline Variable & Cronbach's Alpha \\
\hline Perceived Usefulness (PU) & 0.915 \\
Attitude Towards Participating in Social CRM (ATCRM) & 0.844 \\
Perceived Ease of Use (PEU) & 0.810 \\
Intention (INT) & 0.849 \\
Perceived Enjoyment (PE) & 0.762 \\
User Satisfaction (US) & 0.702 \\
Perceived Risk (PR) & 0.780 \\
\hline
\end{tabular}

\subsubsection{Discriminant Validity}

The square root of average variance extracted (AVE) for each variable should be higher than the values of all correlated variables to meet the requirement of discriminant validity. As illustrated in Table 2, all variables meet this condition. Similarly, for all variables, AVE is higher than maximum shared variance (MSV) and average shared variance (ASV). All constructs meet the minimum threshold of discriminant validity.

\subsubsection{Convergent Validity}

Convergent validity is the extent to which a measure correlates highly with other measures designed to measure the same construct. Having acceptable construct validity means that each construct actually measures what it originally intended to measure (Churchill, 1979). Evidence of convergent validity can be found by checking the AVE of each construct. Fornell and Larcker (1981) suggested that the AVE value for a construct should be minimum 0.50. As the statistics show in Table 2, the AVE values for all constructs exceed 0.5, which confirm the convergent validity. The CRs of all constructs meet the minimum requirement of 0.70 to establish the reliability of the constructs.

There is an alternative way of measuring validity and reliability in addition to the previously discussed methods. This method utilizes composite reliability (CR), AVE, MSV, and ASV to calculate discriminant validity, convergent validity, and reliability. The advantage of this method is all aforementioned validity and reliability measures can be determined by viewing the results of a single table. Table 2 shows the calculated values of CR, AVE, MSV, ASV, and the squared root of the AVE for all variables (shown in bold). Here are the threshold values for validity and reliability: for reliability: CR > 0.7; for convergent validity: CR $>$ AVE and AVE $>0.5$; for discriminant validity: MSV $<$ AVE and ASV $<$ AVE. This alternative method also confirms the validity and reliability of the constructs used in this study. 
Table 2. Calculation of validity and reliability

\begin{tabular}{|c|c|c|c|c|c|c|c|c|c|}
\hline & $\mathrm{CR}$ & AVE & MSV & ASV & PEU & $\mathrm{PU}$ & INT & ATCRM & PR \\
\hline PEU & 0.800 & 0.572 & 0.284 & 0.147 & 0.756 & & & & \\
\hline PU & 0.916 & 0.645 & 0.454 & 0.242 & 0.533 & 0.803 & & & \\
\hline INT & 0.875 & 0.590 & 0.454 & 0.211 & 0.393 & 0.674 & 0.768 & & \\
\hline ATCRM & 0.837 & 0.569 & 0.213 & 0.125 & 0.387 & 0.462 & 0.355 & 0.754 & \\
\hline PR & 0.813 & 0.593 & 0.111 & 0.035 & -0.033 & -0.129 & -0.333 & -0.109 & 0.770 \\
\hline
\end{tabular}

\subsection{Data Analysis}

This research study utilized quantitative data analysis methodologies to test its hypotheses. The efficacy of the research model was analyzed using SPSS (v 21), and Analysis of Moment Structures (AMOS) (v 20). Data analysis was conducted in multiple phases. In the initial phase, demographic analysis was conducted to investigate the demographics of the participants. In the second phase, data screening was performed. In the third phase, exploratory factor analysis (EFA), was performed to identify the number of factors to extract for the research model. EFA also helped detect the variables that were not suitable for the model. In the fourth phase, structural equation modeling (SEM) was conducted, which was the combination of confirmatory factor analysis (CFA) and path analysis. In this phase, CFA was performed to determine whether the measured variables reliably derived from the EFA reflected the hypothesized latent variables. The path analysis was conducted to finalize the structural model derived from the CFA. All hypotheses were tested in this phase. Finally, in the fifth phase, reliability and validity testing were conducted. The reliability test was performed to verify how closely the survey measurements met the objectives of this study, and the validity test was performed to measure the degree to which the measurement instruments truly measure the constructs they intended to measure.

\subsubsection{Exploratory Factor Analysis (EFA)}

EFA with varimax rotation and maximum likelihood analysis factoring method was performed in order to obtain the optimum model structure, and the result was compared with that of the principal component analysis. Both results demonstrated similar findings. The process of removing items and performing the factor extraction was repetitive in nature and was done until a desired factor structure was achieved.

In the final round of EFA, PE and US constructs were dropped because of the low factor loading and Kaiser-Guttman retention criteria of eigenvalues less than 1.0, thus these two constructs have been excluded from subsequent data analysis. The Kaiser-Meyer-Olkin (KMO) measure of sampling adequacy was 0.890 , indicating that the present data were suitable for principal component analysis. Similarly, Bartlett's test of sphericity was significant $(\mathrm{p}<.001)$, indicating sufficient correlation between the variables to proceed with the analysis. Using the Kaiser-Guttman retention criteria of eigenvalues greater than 1.0, a five-factor solution provided the clearest extraction. These five factors accounted for $66.288 \%$ of the total variance. Table 3 presents the factor loading of all constructs.

Factor 1 , PU (eigenvalue $=8.407$ ) accounted for $33.628 \%$ of the variance and had six items; Factor 2, INT (eigenvalue $=2.792$ ) accounted for $11.168 \%$ of the variance and had four items; Factor 3, ATCRM (eigenvalue $=2.227$ ) accounted for $8.909 \%$ of the variance and had four items; Factor 4, PEU (eigenvalue $=1.777$ ) accounted for $7.110 \%$ of the variance and had four items; and Factor 5, PR (eigenvalue $=1.368$ ) accounted for $5.473 \%$ of the variance and had three items. 
Table 3. Factor loading

\begin{tabular}{|c|c|c|c|c|c|}
\hline \multirow[t]{2}{*}{ Constructs and Scale Items } & \multicolumn{5}{|c|}{ Factor Loading } \\
\hline & $\mathrm{PU}$ & INT & ATCRM & PEU & PR \\
\hline \multicolumn{6}{|l|}{ Perceived Usefulness (PU) } \\
\hline $\begin{array}{l}\text { PU4: Participating in the social CRM program would allow me to compare several purchasing } \\
\text { options and choose the best one. }\end{array}$ & .894 & & & & \\
\hline $\begin{array}{l}\text { PU3: Participating in the social CRM program would be more rewarding than a non-CRM } \\
\text { environment. }\end{array}$ & .877 & & & & \\
\hline PU2: Participating in the social CRM program would increase my customer satisfaction. & .827 & & & & \\
\hline PU5: Participating in the social CRM program would enable me to save time. & .797 & & & & \\
\hline PU6: Participating in the social CRM program would allow me to save money. & 689 & & & & \\
\hline PU1: I think participating in the social CRM program is useful. & .668 & & & & \\
\hline \multicolumn{6}{|l|}{ Intention of Participate in Social CRM (INT) } \\
\hline INT3: I am willing to update my profile (personal information) whenever requested. & & .962 & & & \\
\hline $\begin{array}{l}\text { INT2: I am willing to provide personal information (e.g., name, age, address, phone number, } \\
\text { interests, and hobbies) when registering for the social CRM program. }\end{array}$ & & .866 & & & \\
\hline INT1: I am willing to participate in the registration for the social CRM program. & & .552 & & & \\
\hline $\begin{array}{l}\text { INT5: If requested, I am willing to allow a firm's representative to participate in the conversation } \\
\text { with my social friends about its products and services. }\end{array}$ & & .493 & & & \\
\hline $\begin{array}{l}\text { INT4: I am willing to provide feedback on products and services if requested by a firm's } \\
\text { representative. }\end{array}$ & & .475 & & & \\
\hline \multicolumn{6}{|l|}{ Attitude Towards Participating in Social CRM (ATCRM) } \\
\hline ATCRM4: I like the idea of participating in the social CRM program. & & & .866 & & \\
\hline ATCRM 1: Participating in the social CRM program would be a good idea. & & & .837 & & \\
\hline ATCRM 3: Participating in the social CRM program would be a wise idea. & & & .747 & & \\
\hline ATCRM 2: Participating in the social CRM program would be a pleasant experience. & & & .620 & & \\
\hline \multicolumn{6}{|l|}{ Perceived Ease of Use (PEU) } \\
\hline PEU1: Learning how to participate in the social CRM program would be easy for me. & & & & .862 & \\
\hline PEU2: Participating in the social CRM program would be easy for me. & & & & .779 & \\
\hline $\begin{array}{l}\text { PEU3: I would find the Social Networking sites easy to use for participating in the social CRM } \\
\text { program. }\end{array}$ & & & & .655 & \\
\hline \multicolumn{6}{|l|}{ Perceived Risk (PR) } \\
\hline PR1: I am worried that my financial information could be stolen. & & & & & .815 \\
\hline PR2: I am worried that my personal information collected could be misused. & & & & & .750 \\
\hline $\begin{array}{l}\text { PR3: The security systems built into the social CRM program would not be strong enough to } \\
\text { protect my privacy. }\end{array}$ & & & & & 698 \\
\hline
\end{tabular}

As Hair et al. (1998, p. 797) suggested, items exhibiting low factor loading (<.40), high cross-loading $(>.40)$, or low commonalities $(<.50)$ have been deleted. After removing the items that do not contain these minimum required values, EFA was performed again on the remaining items. Additionally, the Kaiser-Meyer-Olkin (KMO) measure of sampling adequacy and Bartlett's test of sphericity were performed to test the adequacy of the distribution of the values for conducting the factor analysis. The KMO value should be higher than 0.60, while a value of 0.90 or higher is considered excellent (George \& Mallery, 2007). The KMO measure of sampling adequacy indicated a practical level of common variance with a value of 0.886 . This indicates that the factor analysis was appropriate.

\subsubsection{Confirmatory Factor Analysis (CFA)}

The CFA was performed multiple rounds until the model reached the satisfactory fit. The hypothesized model was assessed by maximum likelihood analysis in AMOS. This model was evaluated by eight fit measures: (a) $\chi^{2} / d f$, (b) CFI, (c) GFI, (d) AGFI, (e) NFI, (f) IFI, (g) TLI, and (h) RMSEA. Table 4 summarizes the goodness-of-fit results of all three rounds. Among those three rounds, the third model demonstrates the best results in terms of model-fit indices. It has the lowest ratio of chi-square to the degree of freedom $\left(\chi^{2} / d f=1.274\right)$ and the lowest RMSEA value (.032) among all rounds. It also shows the highest values of the CFI, GFI, AGFI, NFI, IFI, and PCLOSE among these three rounds. The AGFI and NFI values are slightly less than the minimum threshold of 0.9 ; however, the GFI, CFI, IFI, and PCLOSE values are above this threshold. The path diagram of the research model test is shown in Figure 2. 
Table 4. Results for model fit indices

\begin{tabular}{|c|c|c|c|c|}
\hline \multirow[t]{2}{*}{ Model Fit Indices } & \multirow[t]{2}{*}{ Recommended Values } & \multicolumn{3}{|c|}{ Obtained Values } \\
\hline & & $1^{\text {st }}$ Round & $2^{\text {nd }}$ Round & $3^{\text {rd }}$ Round \\
\hline$X^{2} / d f$ & $<2$ & 1.778 & 1.362 & 1.274 \\
\hline GFI & $>0.9$ & .885 & .919 & .925 \\
\hline AGFI & $>0.9$ & .851 & .886 & .893 \\
\hline CFI & $>0.9$ & .715 & .878 & .909 \\
\hline IFI & $>0.9$ & .732 & .888 & .917 \\
\hline NFI & $>0.9$ & .544 & .678 & .703 \\
\hline PCLOSE & $>0.9$ & .224 & .967 & .992 \\
\hline RMSEA & $<0.1$ & .054 & .037 & .032 \\
\hline
\end{tabular}

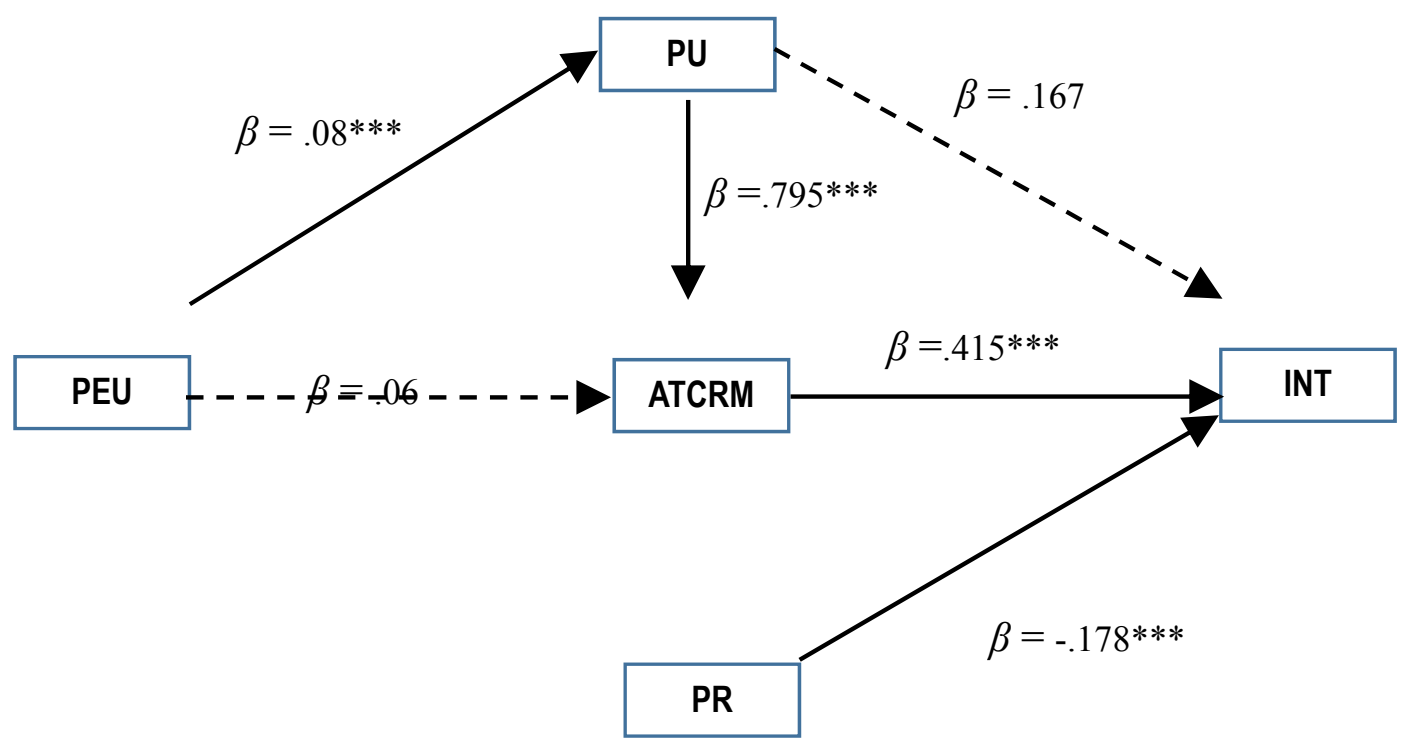

Note. ${ }^{* * *}$ indicates a $p$ value that is statistically significant at 0.001 level.

Solid lines demonstrate statistically significant path at 0.001 level and dotted lines demonstrate statistically non-significant path.

Figure 2. Path diagram of research model

\subsection{Hypothesis Testing}

The structural model revealed an acceptable fit with the data: $\chi^{2}=207.662, d f=163, \chi^{2} / d f=1.274, \mathrm{GFI}=.925$, AGFI $=.893, \mathrm{CFI}=.909, \mathrm{IFI}=.917$, and RMSEA $=.032$. The hypotheses were examined by performing a structural equation model analysis that tested the statistical significance of the standardized path coefficients between constructs of the model. The CFA and the path analysis illustrate that the overall model fit of the study was good. However, some paths between variables were not supported by the data. The standardized path coefficients between variables with corresponding statistical significance and critical ratio are reported in Table 5.

The first hypothesis examined the positive effect of ATCRM on INT. The standardized path coefficient $(\beta=.415$, $p<.001$ ) between ATCRM and INT was 0.415 with a critical ratio of 4.989 , which is significant at the .001 level. Thus, $H 1$ was supported.

The standardized path coefficient $(\beta=.167, p=.046)$ between PU and INT was .167 with a critical ratio of 1.995 , which is not significant at the .001 level. Thus $H 2 a$ was rejected.

PU shows to have positive effect on ATCRM, supporting hypothesis H2b. The standardized path coefficient ( $\beta$ $=.795, \mathrm{p}<.001)$ between PU and ATCRM was .795 with a critical ratio of 18.365 , which is significant at the .001 level. 
As Table 5 indicates, the standardized path coefficient $(\beta=.059, p=.170)$ between PEU and ATCRM was 0.059 with a critical ratio of 1.372 , which is not significant at the .001 level. Thus, $H 3 a$ was rejected.

PEU shows to have positive effect on PU, supporting hypothesis $H 3 b$. The standardized path coefficient $(\beta=.080$, $p<.001)$ between PEU and PU was .080 with a critical ratio of 1.694 , which is significant at the .001 level.

In the final round of EFA, the constructs PE and US were dropped off the research model and data analysis because of the low factor loading. Thus, hypotheses $H 4$ and $H 5$ were rejected.

PR shows to have negative effect on INT, supporting hypothesis $H 6$. The standardized path coefficient $(\beta=-.178$, $p<.001$ ) between PR and INT was -.178 with a critical ratio of -3.487 , which is significant at the .001 level.

Table 5. Standardized regression coefficients, critical ratios, statistical significance between variables, and result of hypotheses

\begin{tabular}{|c|c|c|c|c|c|c|c|}
\hline \multicolumn{4}{|c|}{ Hypothesized Path } & \multirow{2}{*}{$\begin{array}{l}\text { Standardized regression } \\
\text { coefficient } \\
.415\end{array}$} & \multirow{2}{*}{$\begin{array}{l}\text { Critical ratio } \\
4.989\end{array}$} & \multirow{2}{*}{$\begin{array}{l}P \\
* * *\end{array}$} & \multirow{2}{*}{$\begin{array}{l}\text { Result of hypotheses } \\
\text { Supported }\end{array}$} \\
\hline ATCRM & $\rightarrow$ & INT & $H 1$ & & & & \\
\hline PU & $\rightarrow$ & INT & $H 2 a$ & .167 & 1.995 & .046 & Not supported \\
\hline PU & & ATCRM & $H 2 b$ & .795 & 18.365 & $* * *$ & Supported \\
\hline PEU & & ATCRM & $H 3 a$ & .059 & 1.372 & .170 & Not supported \\
\hline PEU & & PU & $H 3 b$ & .080 & 1.694 & $* * *$ & Supported \\
\hline $\mathrm{PE}$ & & INT & $H 4$ & -- & -- & -- & Not supported \\
\hline US & & INT & H5 & -- & -- & -- & Not supported \\
\hline PR & & INT & H6 & -.178 & -3.487 & $* * *$ & Supported \\
\hline
\end{tabular}

Note. ${ }^{* * *}$ indicates a $p$ value that is statistically significant at 0.001 level.

\section{Discussion of Findings}

This study attempts to examine the predictive power of the TAM on customer's intention to participate in the social CRM program. The results of the data reveal that among the original constructs of TAM, ATCRM is the only significant determinant of INT; other two constructs, PU and PEU could not influence INT as their effect was not statistically significant. Thus, it could be concluded that TAM by itself is not a robust model to predict customer's intention to participate in the social CRM program. Among the extended variables, PE and US could not contribute to the research model; only PR significantly influenced the INT.

ATCRM was found to have a direct significant impact on the INT. It implies that if a customer possesses a positive attitude towards CRM, the likelihood of customer's intention to engage is high. The same finding has been reported in numerous consumer studies in a variety of research contexts (Taylor \& Todd, 1995; Sheppard et al., 1988; Shim et al., 2001; Pavlou, 2002; Yousafzai et al., 2007; Shin, 2007), and the current study empirically tested and confirmed this finding in the new field of social CRM.

The second most influential factor in this study is PR. It is not surprising that PR has strong negative effects on INT. If customers think that participating in social CRM programs may lead to a violation of their privacy or security, they will not be interested to engage in social CRM programs. This finding of the current study matches that of numerous previous studies. For example, Bhatnagar, Misra, and Rao (2000), Forsythe and Shi (2003), and Park, Lennon, and Stoel. (2005) found the same result in their studies on online shopping; Pavlou and Gefen (2004) reported the same result in an online auction study; Kim and Prabhakar (2000) also observed the same result in their study on Internet banking.

The results of this study indicated that PU does not have a significant effect on INT. This result was somewhat surprising, since most of the TAM studies found this variable to have an effect on intention (Madden et al., 1992; Bansal \& Taylor, 2002; Armitage \& Christian, 2003). However, there were few studies found no significant impact of PU on intention. Jackson et al. (1997) found no relation between PU and INT. In a study on mobile TV, Choi (2010) found that PU was not a significant predictor of intention to adapt TV services. The finding in the current study implies that customer may believe that social CRM could be useful for them but they are not willing to participate in the social CRM program immediately because of unfamiliarity of the social CRM and risks associated to this participation. 
PU was able to impact customer's attitude. This result was not surprising; prior studies have documented similar findings in information system adoption (Chen et al., 2002; Ha \& Stoel, 2009; Moon \& Kim, 2001; Yu et al., 2008). The result of the current study implies that customers will possess positive attitude towards the social CRM program when they discover that participating in the social CRM program is beneficial, it offers more information about products and services, and it also allows them to compare several purchasing options and leads to saving time and money.

This study found the significant impact of PEU on PU. This finding is in line with other TAM studies (e.g., Davis, 1989; Mathieson, 1991; Moore and Benbasat, 1991; Burton-Jones \& Hubona, 2006; Hassanein \& Head, 2007; Ha \& Stoel, 2009). Davis (1989) found that PEU was an antecedent of PU. Burton-Jones and Hubona (2006) found the significant impact of PEU on PU; Hassanein and Head (2007) reported same result in the online shopping websites. Lu et al (2003) and Ha and Stoel (2009) also claimed that PEU had significant impact on PU. The result of the current study implies that the ease of usage of social media and its associated technologies leads customers to believe that social CRM would offer useful information about products and services and eventually be beneficial for them.

The results of this study found that PEU did not influence attitude. This finding contradicts the results of many previous studies (e.g., Lu et al., 2003; Moore and Benbasat, 1991). However, this finding is also consistent with the findings of a few other contemporary studies. For instance, Davis et al. (1989) did not find any relation between PEU and attitude in the post training period. To et al. (2008) also reported the same finding in a study on instant messaging technology use. Hu et al. (1999) found no evidence to support the relation between PEU and attitude. A possible reason for this finding of current study could be that customers are Internet savvy; the usage of social media and its associated technologies is too easy for them and that easiness does not contribute to their positive attitude towards the social CRM program

The results of this study revealed that US was not one of the variables that influenced customers' intention. This finding of the current study is inconsistent with the results of a few other studies (Oliver, 1980; Yi, 1990). Participants in this study may be satisfied with the social media usage as it was reflected by their high social media usage data. More than three-fourth $(76 \%)$ of the participants use social media for at least half an hour every day; however, this high rate of usage still could not lead them to participate in social CRM programs. This implies that satisfaction in social media usage does not motivate customers to engage in social CRM programs.

This study did not find any significant impact of PE on INT. This finding is inconsistent with some previous studies that found PE to have a significant impact on intention to use a technology (Davis, Bagozzi, \& Warshaw, 1992; Teo et al., 1999; Nysveen et al., 2005; Amin et al., 2007). However, few studies have found the similar results as the current study regarding the impact of enjoyment on technology usage. For instance, Igbaria, Iivari, and Maragahh (1995) observed that PE does not significantly affect the acceptance of data processing systems. Similarly, Pikkarainen et al. (2004) revealed that PE does not significantly affect the use of online banking. One possible reason for the result of this current study is that participants may find that browsing social networking sites is entertaining, pleasant, and an agreeable way of passing time but that it may not confirm their intention to engage in social CRM programs because participants may not find the same pleasure and entertainment in social CRM programs.

\section{Theoretical Contributions}

This study contributes to the body of research on social CRM in two ways. First, this study makes significant contributions to the growing body of literature on the social CRM by providing insights on the factors that affect customer's intention to participate in the social CRM program. Second, by applying the TAM framework to the social CRM, this study extends the overall body of the theoretical knowledge surrounding technology acceptance by demonstrating that among all TAM constructs, attitude and perceived risk are the most critical determinant factors for the intention. The resultant conceptual framework provides a stronger theoretical basis for understanding the behavioral aspect of social CRM implementation.

\section{Practical Contributions}

This research has numerous practical implications for marketers as they implement social CRM programs in their organizations. Identifying the key factors that influence customer intention to engage in a social CRM program has important implications for marketers. The goal of any business entity is to satisfy their customers. To achieve this goal, businesses need to understand their customers very well. Therefore, marketers should focus on enhancing their knowledge of the business's current and potential customers so that they can predict customers' behavior accurately. Prediction of customer's behavior is not an easy task; it demands significant research and experiments on customer behavior. As part of predicting customer's behavior, marketers need to 
understand customer's attitudes and perceptions about the product and company. Marketers also need to investigate to identify the factors that influence customer's decisions. The results of this study will help marketers predict the behavior of customers by identifying the key factors that influence their decisions to participate in a social CRM program. This study can also provide an explanation of what makes a social CRM program successful by identifying the key determinants of customers' behavioral decisions.

The results of this study reveal that ATCRM and PR were the most salient factors for customer's intention to engage in a social CRM program. This knowledge allows marketers to target their marketing efforts and allocate their resources appropriately. Marketers and corporate strategists need to focus on these factors and make them high priorities in the corporate strategy.

Implementing a social CRM program is a costly venture. Before making such a big investment, companies need to perform a feasibility study, identify the risks and challenges, and determine the likelihood of success. It is recommended that, prior to any investment in social CRM implementation, managers identify the areas that need to be focused on in order to influence users' perception about CRM. This study can provide some guidance in identifying the risks and challenges and in determining the likelihood of success or failure of a social CRM program, and subsequently avoid potential risk of failure. The findings of this study can also help marketers explore why huge investments in CRM implementation do not always generate desirable results.

\section{Limitations and Suggestions for Future Research}

The first limitation of this study is that no attempt was made to use the probability sampling. The probability of having sampling-biases exists in this study. The survey was not randomly assigned to the participants by the researcher; rather, participants made their own decisions about participation. Therefore, the random sampling method was not applied to this study. No data was collected through paper-based questionnaires. Some participants may not feel comfortable with filling out a survey on the web. This study missed those participants. Therefore, in a future study, the researcher may consider including an option for a paper-based questionnaire. This study did not perform any comparative analysis among multiple groups or cultures; therefore, the cross-cultural studies to compare the behavior within multiple cultures could be another opportunity. Because of the low factor loading, PE and US did not pass EFA. This opens the doors for future studies, researchers may reinvestigate these two factors in different domains. Also, additional factors can be adapted to this model, and a new model could explain a higher percentage of variance. No attempt was made to investigate the mediating effects of age, income, gender, race, education, or any other variables and mediation effect may exist is some cases. This could be a good opportunity for other researchers to investigate the mediating effect of those factors on customers' intention. Despite the abovementioned limitations, the overall research methodology, the data collection method and all fundamental principles of research have been strictly maintained.

\section{Conclusions}

It has been empirically proven that intention is the predictor of actual use (Sheppard et al., 1988; Shim et al., 2001; Pavlou, 2002; Pikkarainen et al., 2004; Chiu et al., 2005; Cheong \& Park, 2005; Yousafzai et al., 2007; Shin, 2007). Therefore, this study attempted to understand customer usage behavior through identifying the factors that influence customer intention. If a company fails to identify the factors that influence customer's intention, then the company will reasonably fail to understand and predict customer's usage behavior. This study not only identified and analyzed the factors that directly influence customers' intention to participate in social CRM but also examined other factors that had indirect effects on the model. The data analysis examined the direct and indirect effects to determine the total causal effect in the model.

The foundation of CRM was built on the concept of relationship marketing; therefore, the customer relationship is one of the founding pillars of a successful CRM program. In order to build strong customer relationships, companies need to predict customer behavior as accurate as possible. Predicting customer behavior is one of the most challenging parts of every business. Moreover, predicting how and why customers make their purchase decisions is not as clear as it was in the past, especially since the emergence of social media. With the evolvement of social media, customer's purchase decisions have been significantly influenced by peer opinions. A customer can cause a significant impact on a company's reputation because the customer shares his or her experience in the uncensored environment of the social network, and that experience can influence thousands of other viewers' purchase decisions. This is how marketers can utilize customers as a powerful marketing vehicle. At the same time, marketers need to keep in mind that this powerful marketing vehicle may work against the company if the customer had a bad experience with the company, product, or service.

Companies are spending billions of dollars in research to predict customers' behavior, needs, preferences, likings and disliking, and the factors that influence their decisions. Marketing research has even gone to the extent of 
neuromarketing research where customer's brain is scanned through functional magnetic resonance imaging (fMRI) to identify the "buy button" in the brain. All these efforts are dedicated to achieving one common goal: predicting customer's behavior. If a company fails to predict customers, all efforts and resources will be in vain regardless of how good quality of products it produces. This research study is one step towards exploring the world of customer behavior.

References

Adams, D., Nelson, R. R., \& Todd, P. (1992). Perceived usefulness, ease of use, and use of information technology; a replication. MIS Quarterly, 16(2), 227-48. https://doi.org/10.2307/249577

Agarwal, R., \& Prasad, J. (1997). The role of innovation characteristics and perceived voluntariness in the acceptance of information technologies. Decision Sciences, 28, 557-82. https://doi.org/10.1111/j.1540-5915.1997.tb01322.x

Ajzen, I., \& Fishbein, M. (1980). Understanding attitudes and predicting social behavior. Englewood Cliffs, NJ: Prentice Hall.

Amin, H., Baba, R., \& Muhammad, M. Z. (2007). An analysis of mobile banking acceptance by Malaysian customers. Sunway Academic Journal, 4, 1-12.

Askool, S., \& Nakata, K. (2011). A conceptual model for acceptance of social CRM systems based on a scoping study. AI \& Society, 26(3), 205-220. https://doi.org/10.1007/s00146-010-0311-5

Bago, P. (2011). Social customer relationship management. Global Journal of Enterprise Information System, $3(3), 36-45$.

Bandura, A. (1982). Self-Efficacy Mechanism in Human Agency. American Psychologist, 37(2), 122-147. https://doi.org/10.1037/0003-066X.37.2.122

Baran, R. J., Strunk, D. P., \& Galka, R. J. (2008). Principles of Customer Relationship Management. Ohio: Thomson South-Western.

Belletier, C., Robert, A., Motak, L., \& Izaute, M. (2018). Toward explicit measures of intention to predict information system use: An exploratory study of the role of implicit attitudes. Computers in Human Behavior, 86, 61-68. https://doi.org/10.1016/j.chb.2018.04.029

Bhatnagar, A., Misra, S. M., \& Rao, R. H. (2000). On risk, convenience, and Internet shopping behavior. Communications of the ACM, 43(11), 98-114. https://doi.org/10.1145/353360.353371

Bruner, G. C., II, \& Kumar, A. (2005). Explaining consumer acceptance of handheld Internet devices. Journal of Business Research, 58(5), 553-558. https://doi.org/10.1016/j.jbusres.2003.08.002

Burton-Jones, A., \& Hubona, G. S. (2005). Individual differences and usage behavior: revisiting a technology acceptance model assumption. The DATA BASE for Advances in Information Systems, 36(2), 58-77. https://doi.org/10.1145/1066149.1066155

Chen, H. M., \& Vargo, S. L. (2014). Rethinking social CRM design: A service dominant logic perspective. Handbook of Strategic e-Business Management (pp. 767-784). Springer Berlin Heidelberg. https://doi.org/10.1007/978-3-642-39747-9_32

Cheong, J. H., \& Park, M. C. (2005). Mobile Internet acceptance in Korea. Internet Research, 15, 125-140. https://doi.org/10.1108/10662240510590324

Childers, T., Carr, C., Peck, J., \& Carson, S. (2001). Hedonic and utilitarian motivations for online retail shopping behavior. Journal of Retailing, 77(4), 511-535. https://doi.org/10.1016/S0022-4359(01)00056-2

Chiu, C., Hsu, M., Sun, S., Lin, T., \& Sun, P. (2005). Usability, quality, value and e-learning continuance decisions. Computers \& Education, 45(4), 399-416. https://doi.org/10.1016/j.compedu.2004.06.001

Chiu, Y. N., Lin, C. P., \& Tang, L. L. (2005). Gender differs: Assessing a model of online purchase intentions in e-tail service. International Journal of Service Industry Management, 16, 416-435. https://doi.org/10.1108/09564230510625741

Choudhury, M., \& Harrigan, P. (2014). CRM to social CRM: the integration of new technologies into customer relationship management. Journal of Strategic Marketing, 22(2), 149-176. https://doi.org/10.1080/0965254X.2013.876069

Chung, D. (2005). Something for nothing: Understanding purchasing behaviors in social virtual environments. CyberPsychology \& Behavior, 8(6), 538-554. https://doi.org/10.1089/cpb.2005.8.538 
Chung, D. (2016). 10 Surprising Statistics About CRM. Retrieved from https://www.cosmoscrm.com/10-surprising-statistics-about-crm/

Corner, I., \& Rogers, B. (2005). Monitoring qualitative aspects of CRM implementation: The essential dimension of management responsibility for employee involvement and acceptance. Journal of Targeting, Measurement and Analysis for Marketing, 13(3), 267-274. https://doi.org/10.1057/palgrave.jt.5740153

Davis, F. D. (1989). Perceived usefulness, perceived ease of use, and user acceptance of information technology. MIS Quarterly, 13(3), 319-340. https://doi.org/10.2307/249008

Davis, F. D., Bagozzi, R. P., \& Warshaw, P. R. (1989). User acceptance of computer technology: A comparison of two theoretical models. Management Science, 35(8), 982-1003. https://doi.org/10.1287/mnsc.35.8.982

Dillon, A., \& Morris, M. G. (1996). User acceptance of information technology: Theories and models. Annual Review of Information Science and Technology, 31, 3-32.

Direct Marketing News. (2013). 63\% of CRM Initiatives Fail. Retrieved from http://www.dmnews.com/crm/63-of-crm-initiatives-fail/article/303470/

Dishaw, M. T., \& Strong, D. M. (1999). Extending the technology acceptance model with task-technology fit constructs. Information \& Management, 36(1), 9-21. https://doi.org/10.1016/S0378-7206(98)00101-3

Dunn, M. G., Murphy, P. E., \& Skelly, G. U. (1986). Research note: The influence of perceived risk on brand preference for supermarket products. Journal of Retailing, 62(2), 204-216.

Fishbein, M., \& Ajzen, I. (1975). Belief, attitude, intention, and behavior: An introduction to theory and research. Reading, MA: Addison-Wesley.

Forsythe, S. M., \& Shi, B. (2003). Consumer patronage and risk perceptions in Internet shopping. Journal of Business Research, 56(11), 867-875. https://doi.org/10.1016/S0148-2963(01)00273-9

Gartner. (2010). Gartner says majority of consumers rely on social networks to guide purchase decisions [Press release]. Retrieved from http://www.gartner.com/newsroom/id/1409213

Gartner. (2015). Gartner Says Customer Relationship Management Software Market Grew 13.3 Percent. Retrieved from http://www.gartner.com/newsroom/id/3056118

Gatignon, R., \& Robertson, T. S. (1985). A propositional inventory for new diffusion research. Journal of Consumer Research, 11, 849-867. https://doi.org/10.1086/209021

Greenberg, P. (2009). Do we really NEED CRM 2.0? Retrieved from http://www.zdnet.com/blog/crm/do-we-really-need-crm-2-0/302

Greenberg, P. (2010). CRM at the speed of light: Social CRM strategies, tools, and techniques for engaging your customers (4th ed.). New York, NY: McGraw-Hill.

Gruen, T. W., Osmonbekov, T., \& Czaplewski, A. J. (2006). eWOM: The Impact of Customer-toCustomer Online Know-how Exchange on Customer Value and Loyalty. Journal of Business Research, 59(4), 449-456. https://doi.org/10.1016/j.jbusres.2005.10.004

Ha, S., \& Stoel, L. (2009). Consumer e-shopping acceptance: Antecedents in a technology acceptance model. Journal of Business Research, 62(5), 565-571. https://doi.org/10.1016/j.jbusres.2008.06.016

Hair, J. R., Anderson, J. F., Tatham, R. L., \& Black, W. C. (1998). Multivariate data analysis (5th ed.). Upper Saddle River, NJ: Prentice Hall.

Hansen, J. M., Saridakis, G., \& Benson, V. (2018). Risk, trust, and the interaction of perceived ease of use and behavioral control in predicting consumers' use of social media for transactions. Computers in Human Behavior, 80, 197-206. https://doi.org/10.1016/j.chb.2017.11.010

Harrigan, P., \& Miles, M. (2014). From e-CRM to s-CRM. Critical factors underpinning the social CRM activities of SMEs. Small Enterprise Research, 21(1), 99-116. https://doi.org/10.1080/13215906.2014.11082079

Harrigan, P., Soutar, G., Choudhury, M. M., \& Lowe, M. (2015). Modelling CRM in a social media age. Australasian Marketing Journal, 23(1), 27-37. https://doi.org/10.1016/j.ausmj.2014.11.001

Hassanein, K., \& Head, M. (2007). Manipulating Social Presence through the Web Interface and its Impact on Attitude towards Online Shopping. International Journal of Human-Computer Studies, 65(8), 689-708. https://doi.org/10.1016/j.ijhcs.2006.11.018 
Herbig, P. A., \& Day, R. L. (1992). Consumer acceptance: The key to successful introductions of innovations. Marketing Intelligence \& Planning, 10(1), 4. https://doi.org/10.1108/02634509210007812

Hu, P., Chau, P., Liu Sheng, O. R., \& Tam, K. (1999). Examining the Technology Acceptance Model Using Physician Acceptance of Telemedicine Technology. Journal of Management Information Systems, 16(1). 91-112. https://doi.org/10.1080/07421222.1999.11518247

Hung, S. Y., Ku, C. Y., \& Chang, C. M. (2003). Critical factors of WAP services adoption: An empirical study. $\begin{array}{llll}\text { Electronic Commerce Research and } & \text { 42-60. }\end{array}$ https://doi.org/10.1016/S1567-4223(03)00008-5

Igbaria, M., Iivari, J., \& Maragahh, H. (1995). Why do individuals use computer technology? A Finnish case study. Information \& Management, 29(5), 227-238. https://doi.org/10.1016/0378-7206(95)00031-0

Jallat, F., \& Ancarani, F. (2008). Yield management, dynamic pricing and CRM in telecommunications. Journal of Services Marketing, 22(6), 465-478. https://doi.org/10.1108/08876040810901882

Jarvenpaa, S. L., \& Todd, P. A. (1997). Consumer reactions to electronic shopping on the World Wide Web. Journal of Electronic Commerce, 1(2), 59-88. https://doi.org/10.1080/10864415.1996.11518283

June, L., Chun-Seng, Y., Chang, L., \& James, E. Y. (2003). Technology acceptance model for wireless Internet, Internet research. Electronic Networking Application and Policy, 13(3), 206-222. https://doi.org/10.1108/10662240310478222

Kim, K., \& Bonk, C. J. (2006). The future of online teaching and learning in higher education: The survey says. Educause Quarterly, 29(4), 22-30.

Kim, K., \& Prabhakar, B. (2000). Initial trust, perceived risk, and the adoption of Internet banking. Paper presented at the 21st International Conference of Information Systems, Brisbane, Australia.

Kim, M., Park, J. E., Dubinsky, A. J., \& Chaiy, S. (2012). Frequency of CRM implementation activities: A customer-centric view. Journal of Services Marketing, 26(2), 83-93. https://doi.org/10.1108/08876041211215248

Koufaris, M. (2002). Applying the technology acceptance model and flow theory to online consumer behavior. Information Systems Research, 13, 205-224. https://doi.org/10.1287/isre.13.2.205.83

Landry, B. J. L., Griffeth, R., \& Hartman, S. (2006). Measuring Student Perceptions of Blackboard Using the Technology Acceptance Model. Decision Sciences Journal of Innovative Education, 4(1), 87. https://doi.org/10.1111/j.1540-4609.2006.00103.x

Larcker, D. F., \& Lessig, V. P. (1980). Perceived Usefulness of Information: A Psychometric Examination. Decision Sciences, 11(1), 121-134. https://doi.org/10.1111/j.1540-5915.1980.tb01130.x

Leary, B. (2008). Social CRM in pictures and words. Retrieved from http://crm2.typepad.com/brents_blog/2008/07/social-crm-in-p.html

Lu, J., Yu, C. S., Liu, C., \& Yao, J. E. (2003). Technology acceptance model for wireless internet. Internet Research, 13(3), 206-222. https://doi.org/10.1108/10662240310478222

Luo, W., \& Strong, D. (2000). Perceived critical mass effect on groupware acceptance. European Journal of Information Systems, 9(2), 91-103. https://doi.org/10.1057/palgrave.ejis.3000358

Mathieson, K. (1991). Predicting User Intentions: Comparing the Technology Acceptance Model with the Theory of Planned Behavior. Information Systems Research, 2(3), 173-191. https://doi.org/10.1287/isre.2.3.173

Mathieson, K., \& Chin, W. (2001). Extending the technology acceptance model: The influence of perceived user resources. Database for Advances in Information Systems, 32(3), 86-112. https://doi.org/10.1145/506724.506730

McLean, G. (2018). Examining the determinants and outcomes of mobile app engagement: A longitudinal perspective. Computers in Human Behavior, 84, 392-403. https://doi.org/10.1016/j.chb.2018.03.015

Moon, J., \& Kim, Y. (2001). Extending the TAM for a World-Wide-Web context. Information \& Management, 38, 217-230. https://doi.org/10.1016/S0378-7206(00)00061-6

Moore, G. C., \& Benbasat I. (1991). Development of an instrument to measure the perceptions of adopting an information technology innovation. Information Systems Research, 2(3), 192-222. https://doi.org/10.1287/isre.2.3.192 
Nysveen, H., Pedersen, P. E., \& Thorbjornsen, H. (2005). Explaining intention to use mobile chat services: Moderating effects of gender. Journal of Consumer Marketing, 33(5), 247-256. https://doi.org/10.1108/07363760510611671

Oliver, R. L. (1980). A cognitive model for the antecedents and consequences of satisfaction. Journal of Marketing Research, 17, 460-469. https://doi.org/10.2307/3150499

Pan, C. C. (2003). System use of WebCT in the light of the technology acceptance model: A student perspective. (Doctoral dissertation, University of Central Florida). Orlando.

Park, C., \& Jun, J. (2003). A cross-cultural comparison of Internet buying behavior: Effects of Internet usage, perceived risks, and innovativeness. International Marketing Review, 20(5), 534-553. https://doi.org/10.1108/02651330310498771

Park, J., Lennon, S. J., \& Stoel, L. (2005). On-line product presentation: Effects on mood, perceived risk, and purchase intention. Psychology \& Marketing, 22(9), 695-719. https://doi.org/10.1002/mar.20080

Pavlou, P. A. (2002). Institution-based trust in interorganizational exchange relationships: the role of online B2B marketplaces on trust formation. The Journal of Strategic Information Systems, 11(3), 215-243. https://doi.org/10.1016/S0963-8687(02)00017-3

Pavlou, P. A., \& Gefen, D. (2004). Building effective online marketplaces with institution-based trust. Information Systems Research, 15(1), 37-59. https://doi.org/10.1287/isre.1040.0015

Pikkarainen, T., Pikkarainen K., Karjaluoto, H., \& Pahnila S. (2004). Consumer acceptance of online banking: An extension of the technology acceptance model. Internet Research, 14, 224-235. https://doi.org/10.1108/10662240410542652

Prahalad, C. K., \& Ramaswamy, V. (2004). The future of competition: Co-creating unique value with customers. Cambridge, MA: Harvard Business School Press.

Ramayah, T. (2006). Interface characteristics, perceived ease of use and intention to use an online library in Malaysia. Information Development, 22(2), 123-133. https://doi.org/10.1177/0266666906065575

Reichheld, F. F. (1996). The Loyalty Effect. Boston, Massachusetts: Harvard Business School Press.

Robey, D. (1979). User attitude and management information system use. Academy of Management Journal, 22, 527-538.

Schultz, R. L., \& Slevin, D. P. (1975). Implementation and Organizational validity: An Empirical Investigation. Implementing Operations Research Management science, American Elsevier, New York, NY, pp. 153-182

Seddon, P. B. (1997). A re-specification and extension of the DeLone and McLean model of IS success. Information Systems Research, 8, 240. https://doi.org/10.1287/isre.8.3.240

Sheppard, B. H., Hartwick, J., \& Warshaw, P. R. (1988). The theory of reasoned action: A meta-analysis of past research with recommendations for modifications and future research. Journal of Consumer Research, 15(3), 325-343. https://doi.org/10.1086/209170

Shimp, B. (2010). Social CRM, say what? Retrieved from http://allbizanswers.com/2009/05/social-crm-say-what/

Shin, D. (2007). User acceptance of mobile Internet: Implication for convergence technologies. Interacting With Computers, 19(4), 45-59. https://doi.org/10.1016/j.intcom.2007.04.001

Siegel, D. M. (2008). Accepting technology and overcoming resistance to change using the motivation and acceptance model. (Doctoral dissertation, University of Central Florida). Retrieved from http://etd.fcla.edu/CF/CFE0002154/Siegel_Daniel_M_200805_PhD.pdf

Sirivastava, R. K., Shervani, T. A., \& Fahey, L. (1999). Marketing, business process, and shareholder value: An organizationally embedded view of marketing activities and the discipline of marketing, Journal of Marketing, 63(4), 168-179. https://doi.org/10.2307/1252110

Snowden, S., Spafford, J., Michaelides, R., \& Hopkins, J. (2006). Technology acceptance and m-commerce in an operational environment. Journal of Enterprise Information Management, 19(5), 525-539. https://doi.org/10.1108/17410390610703657

Soltani, Z., \& Navimipour, N. J. (2016). Customer relationship management mechanisms: A systematic review of the state of the art literature and recommendations for future research. Computers in Human Behavior, 61, 667-688. https://doi.org/10.1016/j.chb.2016.03.008 
Swan, J. E. (1981). Disconfirmation of Expectations and Satisfaction with a Retail Service. Journal of Retailing, $57(3), 49-66$.

Swilley, E. (2010). Technology rejection: the case of the wallet phone. Journal of Consumer Marketing, 27(4), 304-312. https://doi.org/10.1108/07363761011052341

Szajna, B. (1996). Empirical evaluation of the revised technology acceptance model. Management Science, 42, 85-92. https://doi.org/10.1287/mnsc. 42.1 .85

Taylor, J. W. (1974). The role of risk in consumer behavior. The Journal of Marketing, 54-60. https://doi.org/10.2307/1250198

Taylor, S., \& Todd, P. (1995). Understanding information technology usage: A test of competing models. Information Systems Research, 6, 144-176. https://doi.org/10.1287/isre.6.2.144

Teo, T. S. H., \& Lim, V. K. G. (1997). Usage patterns and perceptions of the Internet: The gender gap. Equal Opportunities International, 16(6/7), 1-8. https://doi.org/10.1108/eb010696

Teo, T. S. H., Lim, V. K. G., \& Lai, R. Y. G. (1999). Intrinsic and extrinsic motivation in Internet usage. $\begin{array}{lllll}\text { International Journal of } & \text { Management }\end{array}$ https://doi.org/10.1016/S0305-0483(98)00028-0

To, P. L., Liao, C., Chiang, J. C., Shih, M. L., \& Chang, C. Y. (2008). An empirical investigation of the factors affecting the adoption of Instant Messaging in organizations. Computer Standards \& Interfaces, 30, 148-156. https://doi.org/10.1016/j.csi.2007.08.019

Tung, L. L. (2004). Service quality and perceived value's impact on satisfaction, intention and usage of short $\begin{array}{lllll}\text { message service (SMS). Information System Frontiers, } 6, & \text { 353-368. }\end{array}$ https://doi.org/10.1023/B:ISFI.0000046377.32617.3d

Venkatesh, V. (2000). Determinants of perceived ease of use: Integrating control, intrinsic motivation, and emotion into the technology acceptance model. Information System Research, 11(4), 342-365. https://doi.org/10.1287/isre.11.4.342.11872

Vroom, V. H. (1964). Work and motivation. New York, NY: Wiley.

Walsh, M. (2010). Social CRM. http://www.slideshare.net/martinwalsh/social-crm-definition-by-martin-walsh

Wu, I., \& Wu, K. (2005). A hybrid technology acceptance approach for exploring e-CRM adoption in

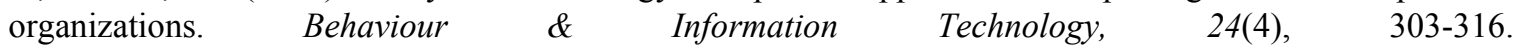
https://doi.org/10.1080/0144929042000320027

Xu, F., \& Du, J. T. (2018). Factors influencing users' satisfaction and loyalty to digital libraries in Chinese universities, Computers in Human Behavior, 83, 64-72. https://doi.org/10.1016/j.chb.2018.01.029

Yi, Y. (1990). A critical review of consumer satisfaction. Review of marketing, 4(1), 68-123.

Yoon, C. (2018). Extending the TAM for Green IT: A normative perspective. Computers in Human Behavior, 83, 129-139. https://doi.org/10.1016/j.chb.2018.01.032

Yousafzai, S., Foxall, G., \& Pallister, J. (2007). Technology acceptance: A meta-analysis of the TAM: Part II. Journal of Modelling in Management, 2(3), 281-304. https://doi.org/10.1108/17465660710834462

Zaremohzzabieh, Z., Abu S, B., Muhammad, M., Omar, S. Z., Bolong, J., Hassan, M. S., \& Shaffril, H. A. M. (2015). A Test of the Technology Acceptance Model for Understanding the ICT Adoption Behavior of Rural Young Entrepreneurs. International Journal of Business and Management, 10(2), 158. https://doi.org/10.5539/ijbm.v10n2p158

\section{Copyrights}

Copyright for this article is retained by the author, with first publication rights granted to the journal.

This is an open-access article distributed under the terms and conditions of the Creative Commons Attribution license (http://creativecommons.org/licenses/by/4.0/). 